\title{
PENGARUH PAD, DAU DAN DAK TERHADAP BELANJA MODAL KOTA DAN KABUPATEN DI PROVINSI BALI
}

\author{
Made Ari Juniawan ${ }^{1}$ \\ Ni Putu Santi Suryantini ${ }^{2}$ \\ ${ }^{1,2}$ Fakultas Ekonomi dan Bisnis Universitas Udayana, Bali, Indonesia \\ email: arikjuniawan@gmail.com
}

\begin{abstract}
ABSTRAK
Anggaran Belanja terutama belanja modal dipandang penting karena berkaitan dengan keberlangsungan kegiatan pemerintahan. Belanja Modal merupakan salah satu bagian dari belanja daerah yang digunakan dalam pembelian atau pengadaan aset tetap berwujud yang mempunyai nilai manfaat lebih dari dua belas bulan digunakan dalam pembangunan infrastruktur dan penyediaan fasilitas publik. Pendapatan daerah dan Belanja Modal saling mempengaruhi. Tujuan penelitian ini adalah untuk mengetahui pengaruh Pendapatan Asli daerah, Dana Alokasi Umum dan Dana Alokasi Khusus terhadap Belanja Modal pada Kota dan kabupaten di Provinsi Bali. Populasi penelitian ini adalah seluruh kabupaten dan kota di Provinsi bali, metode yang digunakan dalam penentuan sampel pada penelitian ini adalah metode sampling jenuh. Alat analisis yang digunakan dalam penelitian ini adalah analisis regresi linier berganda. Hasil dari penelitian ini menemukan bahwa Pendapatan Asli Daerah berpengaruh positif terhadap Belanja Modal, Dana Alokasi Umum berpengaruh positif terhadap Belanja Modal, Dana Alokasi Khusus berpengaruh positif terhadap Belanja Modal..
\end{abstract}

Kata kunci : pendapatan asli daerah, dana alokasi umum, dana alokasi khusus dan belanja modal

\begin{abstract}
The expenditure budget, especially capital expenditure is viewed important because it is related to the continuity of government activities. Capital expenditure, a part of local expenditure, is used in the purchase or procurement of tangible fixed assets with an economic value of more than twelve months, for infrastructure development and to provide public facilities. There are interplays between local revenue and Capital Expenditure. The purpose of this research is to investigate how Original Local Government Revenue, General Allocation Fund and Special Allocation Fund influence Capital Expenditure of Cities and Regencies in Bali Province. The population of this research are all regencies and cities in Bali Province, while sample is determined using total population sampling method. The analysis tool utilized is the multiple linear regression analysis. The result of this research shows that Original Local Government Revenue has positive influence on Capital Expenditure, General Allocation Fund has positive influence on Capital Expenditure, Special Allocation Fund positively influence Capital Expenditure.
\end{abstract}

Keyword : original local government revenue, general allocation fund, special allocation fund and capital expenditure 


\section{PENDAHULUAN}

Otonomi daerah atau Desentralisasi pada Undang-Undang Nomor 32 Tahun 2004 yang menjelaskan kewajiban pemda untuk mengendalikan daerahnya dengan tetap mengikuti aturan dan undang-undang yang berlaku. Menurut Sukarna (2013:8) kekuasaan daerah otonomi sangat luas karena pemerintah daerah berwenang mengurus sendiri kepentingan masyarakatnya yang terdiri dari bidang pendidikan, pertanian, kesejahteraan, kesehatan, perumahan, perekonomian dan lain-lain. Berbeda halnya dengan pemerintah pusat hanya menangani beberapa kewenangan birokrasi luar negeri, keamanan dan ketertiban, dan keuangan nasional, pertahanan, yustisi dan agama. Desentralisasi mengakibatkan pemrintah daerah harus mampu untuk meningkatkan sumber daya daerahnya (Basri, 2012:177). Potensi daerah dapat ditingkatkan melalui peningkatan anggaran belanja daerah.

Menurut Mahmudi (2010:87) Belanja daerah dipisahkan dua bentuk yang terbagi atas Belanja Operasi dan Belanja Modal. Belanja Operasi yang hakekatnya merupakan biaya (expense) untuk membiayai kegiatan non investasi yang memiliki kegunaan kurang dari 1 tahun, berbeda halnya dengan Belanja Modal dalam pengertiannya merupakan belanja investasi berupa biaya sehingga diakui neraca. Manajemen belanja daerah harus menjadi fokus pemerintah daerah agar optimalisasi manajemen keuangan daerah dapat tercapai (Mahmudi, 2010:82).

Belanja Daerah yang termasuk belanja modal patut diperhitungan karena berkaitan dengan keberlangsungan pembangunan infrastruktur dan fasilitas publik. Belanja Modal dalam pemahamannya berhubungan dengan upaya pemerintah untuk menyediakan fasilitas agar menunjang kinerja pemerintah dalam upaya 
memberikan pelayanan yang sebaik mungkin kepada masyarakat. Menurut Halim (2014:229) Belanja Modal yaitu salah satu kelompok dari belanja daerah yang digunakan dalam pembelian dan penyediaan barang berwujud memiliki daya guna satu tahun lebih yang dipeegunakan dalam pembangunan infrastruktur dan penyediaan fasilitas publik. Menurut Felix (2012) peningkatan Belanja Modal yang di anggarkan mengakibatkan peningkatan Belanja Modal dalam kaitannya penambahan infrastruktur dan sarana prasarana publik. Belanja Modal dalam pemahamannya berhubungan dengan upaya pemerintah untuk menyediakan fasilitas, sarana dan prasarana yang dapat menunjang kinerja pemerintah dalam upaya memberikan pelayanan yang sebaik mungkin kepada masyarakat.

Pelaksanaan desentralisasi memberikan konsekuensi bertambahnya kewenangan pemerintah daerah dalam meningkatkan pendapatan daerah (Sukarna, 2013:9). Dengan adanya pemberian otonomi daerah memberikan pemahaman bahwa setiap daerah diharuskan sanggup memenuhi kebutuhan semua kegiatan pelayanan, pembangunan infrastruktur dan penyediaan publik fasilitas yang menjadi kewajiban setiap pemerintah daerah.

Pemerintah daerah diarahkan untuk bisa dalam mengelola penerimaan daerahnya sendiri yang ditunjukkan untuk pembangunan perekonomian daerah. Peningkatan desentralisasi berkaitan dengan bagaimana daerah mampu dalam menggali penerimaan atau pemasukan yang berasal dari dalam daerah itu sendiri. PAD (Pendapatan Asli Daerah) bagian dari pemasukan daerah yang digali dari sumber daya yang tersedia di daerah yang tidak termasuk dana perimbangan dan penerimaan lainnya. Mbedzi and Gondo (2010) menemukan Sumber pendapatan 
utama untuk daerah yang meliputi pajak, retribusi dan hasil perusahaan milik daerah berpengaruh positif terhadap Belanja Modal. Nani and Vitor (2012) menemukan bahwa pendapatan daerah dan Belanja Modal saling mempengaruhi satu sama lain yang berarti bahwa perubahan dalam pendapatan daerah dapat mengakibatkan perubahan Belanja Modal. Menurut Venkataraman and Urmi (2017) Ditemukan Bahwa dalam jangka pendek dan jangka panjang, penerimaan daerah yang berupa PAD memiliki dampak positif kepada Belanja Modal pada bidang pembangunan daerah.

Penerapan desentralisasi fiskal di Indonesia secara formal dimulai dengan diterapkannya Undang-Undang Nomor 33 Tahun 2004 yang menjelaskan perimbangan finansial mengatur pendanaan dari pusat ke pemda. Desentralisasi fiskal adalah cara untuk meningkatkan kinerja ekonomi publik sehingga berdampak positif bagi pertumbuhan ekonomi (Sukarna, 2013:34). Masing-masing daerah memiliki kesanggupan keuangan yang berbeda dalam mendanai aktivitas-aktivitas pemerintahannya, terutama dalam pengelolaan Pendapatan Asli Daerahnya. Perbedaan kemampuan keuangan di setiap daerah dapat menyebabkan ketimpangan keuangan antara satu daerah dengan daerah lainnya. Kebijakan desentralisasi fiskal bertumpu pada bantuan dari pemerintah pusat untuk membantu kebutuhan pemerintah daerah melalui pembiayaan dalam pelaksanaan desentralisasi.

Alokasi finansial dari pusat ke pemda diantaranya Dana Alokasi Umum yang diberikan untuk memberikan manfaat finansial yang merata seragam dalam pelaksanaan kegiatan pemerintahan daerah (UU No. 33 Tahun 2004). Menurut Sukarna (2013:42) Dana Alokasi Umum atau DAU daerah pemberiannya dihitung 
berdasarkan kemampuan keuangan daerah yang didapatkan dari selisih kebutuhan daerah dengan kemampuan yang dimiliki daerah. Pemberian Dana Alokasi Umum untuk daerah yang memiliki keuangan yang mencukupi namun keperluan keuangannya kecil maka mendapatkan anggaran Dana Alokasi Umum yang kecil, begitu juga sebaliknya.

Pemerintah pusat memiliki program untuk mengurangi ketimpangan daerah berupa Dana Alokasi Khusus atau DAK yang didapatkan melalui Penerimaan APBN yang diberikan untuk daerah terpilih yang bertujuan menbiayai sesuai keperluan daerah yang seragam dengan program nasional (UU No. 33 Tahnu 2004). Penggunaan anggaran DAK ditujukkan untuk kegiatan investasi jangka panjang, investasi jangka pendek, peningkatan kinerja daerah, perbaikan dan peningkatan sarana dan prasarana pelayanan masyarakat tergolong dalam prioritas nasional dengan umur ekonomis yang panjang dan termasuk dalam pengeluaran Belanja Modal (Sukarna, 2013:43).

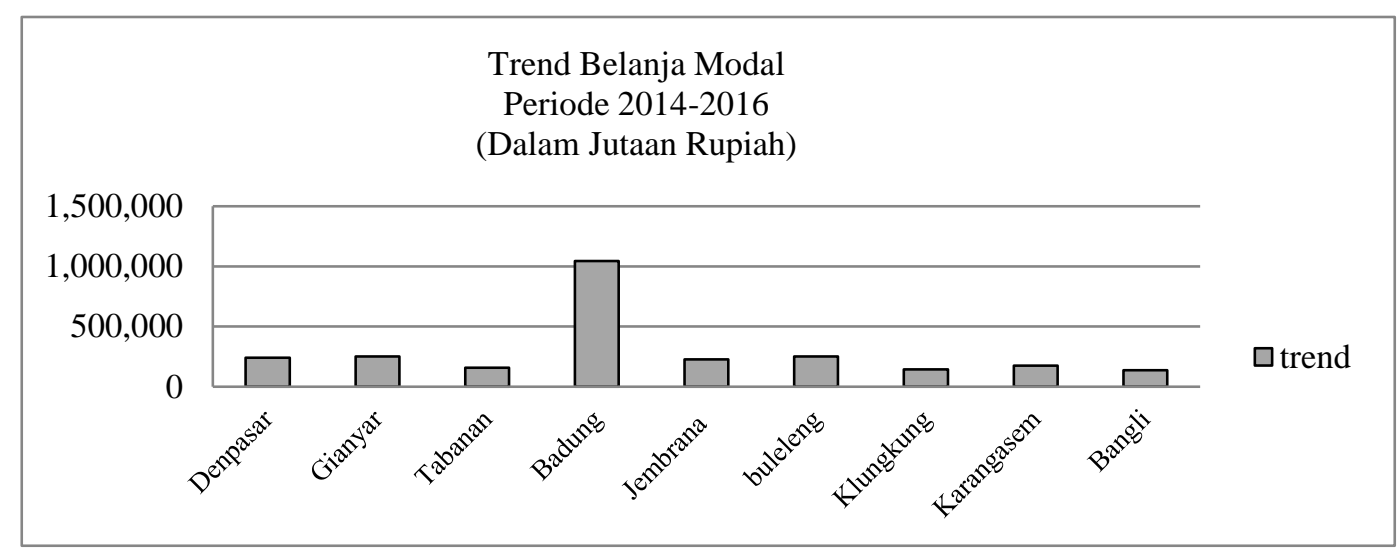

Gambar 1. Grafik Trend Belanja Modal Kota dan Kabupaten di Provinsi Bali Sumber: BPS Provinsi Bali dalam Angka 2014-2016

Berdasarkan grafik dapat dijelaskan bahwa dari 1 kota dan 8 kabupaten di Provinsi Bali memiliki perbedaan trend Belanja Modal yang signifikan. Kabupaten 
Badung mengalami trend Belanja Modal tertinggi, sedangkan Kabupaten Bangli mengalami trend Belanja Modal paling rendah. Belanja Daerah yang termasuk belanja modal patut diperhitungan karena berkaitan dengan keberlangsungan pembangunan infrastruktur dan fasilitas publik. Anggaran Belanja Modal daerah yang meningkat dalam pencapaiannya dapat diartikan pemerintah daerah dapat memberikan fasilitas publik secara maksimal. Penerimaan daerah diantaranya Pendapatan Asli Daerah, DAU dan DAK diperuntukkan pemda untuk meningkatkan pelayanan ke masyarakat melalui fasilitas publik dapat nantinya akan meningkatkan Belanja Modal. Meningkatnya perekonomian daerah disertai dengan penerimaan daerah yang meningkat, seharusnya dapat meningkatkan Belanja Modal daerah (Adyatama dan Rahmawati, 2015).

Berdasarkan penelitian Pendapatan Asli Daerah terhadap Belanja Modal sebelumnya, Gounder et al. (2007) dan Abba (2015) menemukan PAD positif terhadap Belanja Modal sedangkan V Sebastiana dan Cahyo (2016), Nurlis (2016) menemukan bahwa PAD negatif terhadapaBelanjaaModal.

Berdasarkan penelitian Dana Alokasi Umum dan Belanja Modal sebelumnya, Sumarsono dan Rahmawati (2017), Abdillah and Mursinto (2016) menemukan bahwa DAU berpengaruh positif terhadap Belanja Modal sedangkan Purbarini and Masjojo (2015) dan Nurlis (2016) menemukan bahwa DAU berpengaruh negatif terhadap Belanja Modal.

Berdasarkan penelitian Dana Alokasi Khusus dan Belanja Modal sebelumnya, Sugiyanta (2016), Novianto dan Hanafiah (2015) menemukan bahwa DAK positif terhadap Belanja Modal sedangkan Heliyanto dan Hadayani (2016), 
Febriana dan Praptyo (2015) menemukan bahwa DAK negatif terhadap Belanja Modal.

Berdasarkan penelitian sebelumnya terdapat perbedaan hasil temuan, sehingga menjadi celah penelitian ini dilakukan dengan tujuan untuk memperjelas bagaimana penerimaan daerah yang diantaranya PAD, DAU dan DAK mempengaruhi Belanja Modal. Berdasarkan latar brlakang yang telah dijelaskan, penelitian ini dilakukan di 1 kota dan 8 kabupaten yang tersebar di Provinsii Bali karena berdasarkan trend Belanja Modal pada daerah diantaranya 1 kota dan 8 kabupaten di Provinsi Bali tidak merata yang menyebabkan adanya perbedaan pelayanan dan fasilitas publik di masing-masing kabupaten atau kota.

Berdasarkan penjelasan sebelumnya, tedapat tiga pokok permasalahan yang akan diperjelas dalam penelitian ini. Ketiga masalah tersebut diantaranya: (1) Apakah PAD berpengaruh terhadap Belanja Modal kota dan kabupaten di Provinsi Bali?; (2) Apakah DAU berpengaruh terhadap Belanja Modal kota dan kabupaten di Provinsi Bali?; (3) Apakah DAK berpengaruh terhadap Belanja Modal kota dan kabupaten di Provinsi Bali?

Berdasarkan permasalahan yang dijelaskan, maka penelitian ini bertujuan diantaranya (1) Untuk mengetahui PAD berpengaruh terhadap Belanja Modal kota dan kabupaten di Provinsi Bali; (2) Untuk mengetahui DAU berpengaruh terhadap Belanja Modal kota dan kabupaten di Provinsi Bali; (3) Untuk mengetahui DAK berpengaruh terhadap Belanja Modal kota dan kabupaten di Provinsi Bali.

Manajemen keuangan sektor publik secara sederhana didefinisikan bagaimana pemerintah mencari sumber pendapatan dan bagaimana pemerintah 
mengalokasikannya (Halim, 2014:168). Menurut Yuwono (2005) dalam Heliyanto dan Handayani (2016) mendefinisikan anggaran yaitu suatu bentuk rencana berbentuk angka yang umumnya dalam satuan mata uang yanf bertujuan menjelaskan angka perolehan dan pencapaian suatu organisasi. Keuangan daerah memiliki definisi yaitu segala kebutuhan dan keharusan daerah untuk menjalankan pemerintahan melalui alat ukur satuan uang yang diantaranya terdapat jumlah kekayaan daerah beserta kewajiban dan hak dalam Anggaran Pendapatan dan Belanja Daerah (Saragih, 2003:82). Perencanaan memiliki bagian yang utama dalam proses manajemen organisasi. Perencanaan juga berkaitan dengan anggaran yang mempunyai posisi yang sangat penting.

Desentralisasi merupakan keberhakan, kebutuhan, kekuasaan daerah untuk mengendalikan, melaksanakan daerahnya denganzperaturan danzperundangundangan yang berlakuyang sesuai dengan UU.No.32Tahun2004. Desentralisasi atau Otonomidaerah mewajibkan penyelenggara daerah dengan masyarakat saling berkesinambungan dalam pembangunan daerahnya masing-masing (Arini, 2015). Menurut Mardiasmo (2002:98) desentralisasi menyebabkan masing-masing daerah diharapkan sanggup mencari sumber-sumber pendapatan untuk kebutuhan pembangunan dengan tidak berharap terlalu besar terhadap keinginan ketergantugan bantuan dari dana perimbangan dari Pemerintah Pusat.

Tujuan kegiatan otonomi daerah atau desentralisasi, yaitu menghindari bergantungnya daerah terhadap pemerintah pusat terutamnya dalam pengelolaan fiskal. Menghindari bergantung terhadap pemerintah pusat dapat dilakukan salah satunya dengan mengelola Pendapatan Asli daerah dengan semaksimal mungkin. 
(Mahmudi, 2010: 18). Undang Undang Nomor 32 Tahun 2004 memliki definisi PAD diantaranya penerimaan didapatkan dari daerah yang diambil dari peraturan yang dimiliki oleh daerah seragam dengan undang-undang yang berlaku. Menurut Mahmudi (2010:18) Semakin tinggi kemampuan daerah dalam mendapatkan dan menggali Pendapatan Asli Daerahnya, maka semakin tinggi pengeluaran daerah untuk meningkatkan Pendapatan Asli Daerahnya yang selaras dengan keinginan, keperluan dan pembangunan.

Berdasarkan UU No. 33 tahun 2004 menjelaskan bahwa DAUmerupakna danaayang didapatkan melalui penerimaan dalam negeri diberikan dari pusat ke pemda dengan harapan keadilan finansial antar daerah yang digunakan membiayai keperluan belanja untuk menyelenggarakan desentralisasi. Kemampuan keuangan setiap daerah berbeda-beda dalam melaksanakan kegiatan terutamanya dalam desentralisasi fiskal, dengan adanya permasalahan ini, pemerintah pusat membuat kebijakan transfer dari pusat untuk daerah. Halim (2007:90) menjelaskan pengalokasian dana dari penerimaan APBN yang diberikan dengan harapan pemerataan finansial daerah untuk memenuhi pendanaan daerah yang berkaitan dengan penyelenggaraan desentralisasi fiskal atau otonomi daerah yaitu Dana Alokasi Umum. Salah satu tujuan penting pengalokasian Dana Alokasi Umum, yaitu dalam pemenuhan kebutuhan untuk pemerintah daerah dalam halnya penyediaan pelayanan publik yang lebih baik (Halim, 2014:118). Terbukti bahwa Dana Alokasi Umum dapat dijadikan penyeimbang dalam pembagian dana daerah yang sesuai dengan kemampuan daeah yang kurang ataupun kemampuan keuangan daeah yang lebih tidak semua dimiliki oleh daerah yang tersebar di Indonesia. 
Menurut Mardiasmo (2002:158) perhitungan Dana Alokasi Umum didasarkan pada faktor murni yaitu dana yang diberikan dari pusat berupa Dana Alokasi Umum diberikan dengan cara perhitungan rumus sedangkan faktor penyeimbang yaitu kebijakan yang bertujan mengurangi penurunan kemampuan daerah dalam memenuhi kewajibannya di daerah dalam kegiatan pembelanjaan yang merupakan tanggung hawab masing-masing daerah.

Berdasarkan UU No. 33 tahun 2004 menjelaskan DAK yaitu bantuan finansial berasal yang diberikan pemerintah pusat yang secara khusus diberikan di daerahtertentu yang digunakannmendanai keperluan daerah secara khusussyang merupakan kebutuhan seragam dengan program nasional. Tujuan Dana Alokasi Khusus adalah membiayai keperluan dasar yang pada dasarnya merupakan kegiatan program nasional baik dibidang pendidikan, kesehatam, lingkungan hidup, pekerjaan umum, air bersih, perikanan, pemerintahan, sanitasi, kelautan, pertaniam, kehutanan, keluarga berencana, perdagangan dan sarana prasarana desa (Halim, 2014:138). Transfer dari pemerintahan pusat ke daerah selain sebagai sumber penerimaan daerah, dapat digunakan sebagai jaminan tercapainya standar pelayanan minimum di suatu negara. Pencapaian program atau kegiatan yang didanai menggunakan Dana Alokasi Khusus pada anggaran yang berjalan diwajibkan sudah dapat digunakan pada akhir tahun anggaran (Halim, 2014:143). Menurut Sukarna (2013:44) Penentuan jumlah bantuan Dana Alokasi Khusus yang diperuntukkan kepada tiap-tiap daerah diberikan sesuai dengan perhitungan berddasarkan kriteria khusus, kriteria umum dan kriteria teknis. 
Istilah belanja dalam sektor publik pada umumnya berkaitan dengan penganggaran yang dapat menjelaskan angka besaran uang telah digunakan selama satu periode anggaran. Belanja modal dalam pemahamannya yaitu kegiatan pembiayaan berupa investasii dan dalam kelanjutannya dimasukkan dalam neraca (Mahmudi, 2010:87). Belanja Modal Menurut Halim (2014:229) dijelaskan salah satu dari belanja daerah yang dapat didefinisikan sebagai pembiayaan berupa pengeluaran dilaksanakan pada melaksanakan kegiatan pengadaan, pembelian ataupun penyediaan aset berwujud tetap yang memiliki umur kegunaan lebih satu tahun yang diaplikasikan untuk penyediaan fasilitas publik dan infrastruktur. Belanja Modal yaitu kegiatan yang berupa pengeluaran yang diperlukan mendanai keperluan infrastruktur (Henley, 1990:56). Belanja modal merupakan penggunaan dana yang nantinya dapat meningkatkan aset daerah dan dapat meningkatkan biaya pemeliharaan dan perawatan didalamnya. (Mardiasmo, 2002:187). Dengan diadakannya belanja modal, dapat berdampak secara menyeluruh meliputi makro dan mikro untuk perekonomian nasional, terutamnya perekonomian daerah. (Halim, 2014:228). Menurut Ayinde et al. (2015) pengunaan dana yang dilakukan oleh pemerintha pada kegiatan khusus yang dipergunakan memaksimalkan pelayanan dan fasilitas masyarakat dalam jangka waktu panjang adalah Belanja Modal.

Berdasarkan konsep-konsep yang dirujuk, dapat dijelaskan penelitian ini melalui gambar kerangka konseptual pada Gambar 2, sehingga dipergunakan untuk perumusan hipotesis dalam penelitian.

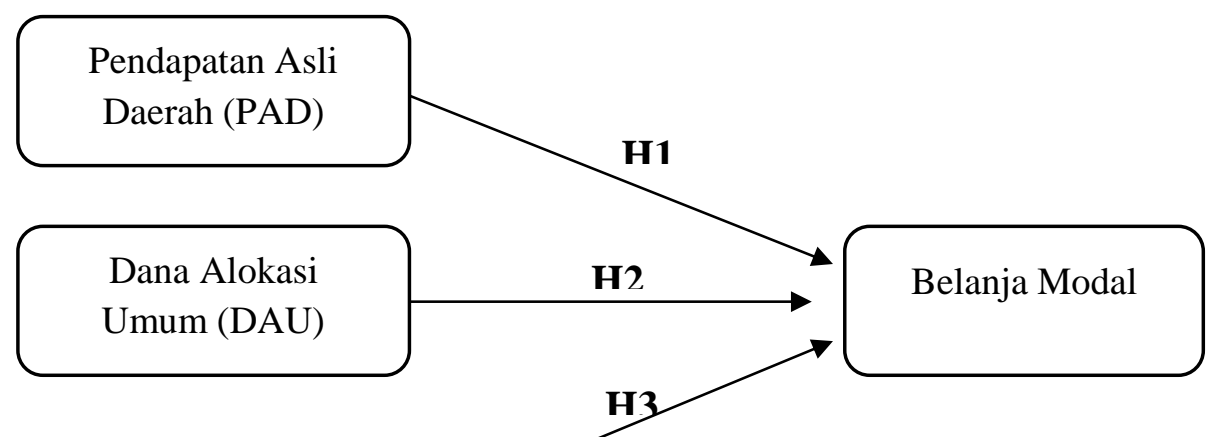


Made Ari Juniawan, Pengaruh PAD...

Gambar 2. Kerangka Konseptual Penelitian

\section{HIPOTESIS PENELITIAN}

\section{Pengaruh PAD Terhadap Belanja Modal}

Desentralisasi mengakibatkan pemda wajib mampu menggali penerimaan daerah yang peruntukannya mendanai kebutuhan daerah dalam rangka meningkatkan pengadaan sarana dan prasarana. Menurut Halim (2014) desentralisasi untuk daerah dalam merancang dan mengelola keuangan daerah sesuai dengan kondisi daerah, potensi sumber pendapatan dominan penyumbang Pendapatan Asli Daerah untuk rata-rata pemda Indonesia bersumber dari pemungutan pajak daerah dan retribusi daerah (Halim, 2014). Penelitian Susanti dan Fahlevi (2016), Purbarini and Masjojo (2015) dan Tuasikal (2008) menemukan bahwa PAD positif terhadap Belanja Modal. Berdasarkan penemuan sebelumnya, Jayadan Dwirandra(2014) menemuka semakin besar PAD maka penerimaan tersebut digunakan dalam penyediaan dan pengadaan pelayanan dan fasilitas publik yang terbaik sehingga besar juga Belanja Modalnya. Berdasarkan pemikiran tersebut, penelitian ini dapat mengajukan hipotesis diantaranya:

$\mathrm{H}_{1}$ : PAD berpengaruh positif terhadap Belanja Modal. 


\section{Pengaruh DAU Terhadap Belanja Modal}

Adapun tujuan dari transfer salah satunya dalam bentuk Dana Alokasi Umum yaitu untuk mengurangi perbedaan keuangan dan kemampuan pendanaan antar daerah, dengan cara ini maka pemberian Dana Alokasi Umum antar daerah tidak sama jumlahnya. Daerah dapat memakai dana transfer yang berupa bantuan Dana Alokasi Umum yang digunakan untuk penyediaan fasilitas dan pelayanan yang terbaik melalui Belanja Modal. Semakin besar DAU yang diberikan dari pusat, maka semakin besar juga penyediaan dan pengadaan pelayanan dan fasilitas publik yang terbaik melalui Belanja Modal daerah. Dana Alokasi Umum dikelola secara penuh oleh pemerintah daerah didalam penggunaanya sesuai dengan kebutuhan dan keperluan suatu daerah. Penelitian Permatasari dan Mildawati (2016), Wahyuningsih dan Widaryanti (2015) dan Pentury (2011) menemukan DAU positif terhadap Belanja Modal. Berdasarkan pemikiran tersebut, penelitian ini dapat mengajukan hipotesis diantaranya:

$\mathrm{H}_{2}$ : DAU berpengaruh positif terhadap Belanja Modal.

\section{Pengaruh DAK Terhadap Belanja Modal}

DAK adalah pendanaan yang besumber dari AnggarannPendapatann Belanja Negara untuk setiap daerah tertentu yang bertujuan sebagai memdanai keperluan khusus melingkupi kebutuhan daerah yang merupakan kebutuhan seragam dengan program nasional. Pendanaan ini diutamakan untuk daerah-daerah tertentu yang memenuhi kriteria untuk memperoleh tambahan dana dari pusat yang melalui DAK. Penelitian Paramartha dan Budiasih (2016), Novianto dan Hanafiah (2015) dan Martini, dkk (2014), menjelaskan DAK positif terhadap Belanja Modal. 
Semakin besar DAK yanggdiberikan olehhpusat, makassemakin besarrjuga penyediaan dan pengadaan pelayanan dan fasilitas terbaikmmelalui Belanja Modal daerah. DAK kepada Belanja Modal ditemukan positif karena pemberian DAK diprioritaskan untuk mencapai tujuan dari program atau kegiatan tertentu untuk daerah yang menerima Dana Alokasi Khusus. Berdasarkan pemikiran tersebut, penelitian ini dapat mengajukan hipotesis diantaranya:

$\mathrm{H}_{3}$ : DAK berpengaruh positif terhadap Belanja Modal.

\section{METODE PENELITIAN}

Berdasarkan latar belakang sebelumnya, penelitian ini berlokasi di Provinsi Bali yang menyertakan satu kota delapan kabupaten. Data pada penelitian ini menggunakan jenis data yang berupa data kuantitatif yang bisa dihitung jumlahnya. Berkaitan dengan bagaimana anggaran sebelumnya yang akan diteliti, maka memerlukan data kuantitatif berbentuk RAPBD TA 2014-2016 1 kota dan 8 kabupaten di Provinsi Bali terutamnaya yang mencantumkan PAD, DAU, DAK dan Belanja Modal sebagai data kuantitatif penelitian ini. Kumpulan data penelitian merupakan data sekunder yang didapatkan dari RAPBD Kota dan Kabupaten di Provinsi Bali yang didapatkan langsung dari kantor Badan Pusat Statistik Provinsi Bali dan website resmi Badan Pusat Statistik Bali (bali.bps.go.id). Berdasarkan pembahasan sebelumnya, dapat dijelaskan yang digunakan metode dalam penelitian ini yaitu kuantitatif yang menggunakan satu tiga variabel independennyang terbagi dari PAD (X1), DAU (X2), DAK (X3) dan satu variable dependennBelanja Modal (Y). Berdasarkan penjelasan sebelumnya, objek penelitian yang digunakan diantaranya PAD, DAU, DAK vairabel independenn dan 
Belanja Modal sebagai variabel dependen pada kota dan kabupaten di Provinsi Bali pada tahun 2014-2016.

Menggunakan populasi yang dapat dijabarkan yaitu seluruh daerah di Provinsi Bali terbagi atas satu kota dan delapan kabupaten. Penjelasan bahwa populasi penelitian merupakan seluruh kota dan kabupaten di Provinsi Bali maka digunakan metoda pemilihan sampel penelitian ini merupakan metode sampling jenuh, bilamana semua anggota populasi diperlukan untuk sampel penelitian. Seluruh kabupaten dan kota di Provinsi Bali termasuk dalam sampel penelitian ini. Teknik pengujian data menggunakan Uji Asumsi Klasik dan teknik analisis data yang digunakan yaitu model regresi berganda untuk menguji pengaruh variabel independen PAD, DAU dan DAK terhadap variabel dependen Belanja Modal.

\section{HASIL DAN PEMBAHASAN}

Sebelum model regresi digunakan untuk menguji hipotesis, terlebih dahulu sebelumnya dilakukan pengujian ketepatan model penelitian berupa uji asumsi klasik. Berdasarkan data yang diperoleh dengan metode pengumpulan data didapatkan deskripsi data tentang variabel penelitian seperti pada Tabel 1. Dibawah ini.

\section{Hasil Uji Asumsi Klasik}

Tabel 1.

Uji Normalitas

\begin{tabular}{lc}
\hline & Unstandarized Residual \\
\hline $\mathbf{N}$ & 27 \\
Asymp. Sig. (2-Failed) & .145 \\
\hline
\end{tabular}

Sumber: Data Diolah, 2017 
Pada Tabel 1. menunjukkan hasil angka model persamaan yang diuji sebesar 0,145 pada Asymp.aSig.a(2-Failed) yang lebihabesar dari 0,05. Dari perhitungan tersebut menjelaskan angka dalam model regresi terdistribusi normal.

Tabel 2.

Uji Autokorelasi

\begin{tabular}{cccccc}
\hline Model & R & R Square & $\begin{array}{c}\text { Adjusted R } \\
\text { Square }\end{array}$ & $\begin{array}{c}\text { Std. Error of the } \\
\text { Estimate }\end{array}$ & Durbin-Watson \\
\hline 1 & .837 & .700 & .651 & 19.02795 & 2.099 \\
\hline Sumber: Data Diolah, 2017 & & & &
\end{tabular}

Tabel 2. Menunjukkan angka DW (Durbin-Watson) yaitu 2,099 dengan rincian tabelaDurbin-Watson dengan $\mathrm{n}=27$ dan $\mathrm{k}=3$ dan tingkat signifikansi $5 \%$ menunjukkan nilai $\mathrm{dL}=1,16$ dan $\mathrm{dU}=1,65$. Nilai $\mathrm{DW}=2,09$ lebih besar dari $\mathrm{dU}$ yakni 1,65 atau kurang dari (4-dU) 4-1,65 = 2,35 dengan demikian tidak ada gejala autokorelasi karena berada daerah tidak terdapat autokorelasi.

Tabel 3.

Uji Multikolinearitas

\begin{tabular}{ccc}
\hline \multirow{2}{*}{ Model } & \multicolumn{2}{c}{ Colinearity Statistics } \\
& Tolerance & VIF \\
\hline 1 (Constant) & & \\
PAD & .964 & 1.037 \\
DAU & .916 & 1.091 \\
DAK & .911 & 1.098 \\
\hline
\end{tabular}

Sumber: Data Diolah, 2017

Pada Tabel 3. menunjukkan hasil perhitungan angka tolerance lebih besar dari 0,1 ataupun angka VIF lebih kecil dari 10. Dari angka temuan menjelaskan tidak terjadi multikolinearitas.

Tabel 4.

Uji Heteroskedastisitas

\begin{tabular}{lcc}
\hline \multicolumn{1}{c}{ Model } & $\mathbf{t}$ & Sig \\
\hline 1 (Constant) & 1.765 & .091 \\
PAD & .802 & .431 \\
DAU & -.043 & .966 \\
DAK & .272 & .788 \\
\hline Sumber: Data Diolah, 2017 & &
\end{tabular}


Berdasarkan Tabel 4. menjelaskan sig PAD, DAU dan DAK lebih besar dari 0,05 dari angka perhitungan dapat ditarik kesimpulan tidak adanya gejala heteroskedastisitas model regresi.

\section{Hasil Regresi Linier Berganda}

Tabel 5.

Analisis Regresi Liner Berganda

\begin{tabular}{lcc}
\hline \multirow{2}{*}{ Model } & \multicolumn{2}{c}{ Unstandarized Coefficients } \\
& B & Std. Error \\
\hline 1 (Constant) & -20.888 & 9.469 \\
PAD & .648 & .285 \\
DAU & 5.289 & .789 \\
DAK & .014 & .006 \\
\hline
\end{tabular}

Sumber: Data Diolah, 2017

Berdasrkan persamaan hasil perhitungan dapat dijabarkan: (1) Angka koefisien sebesar -20,888 menjelaskan apabila angka PAD (X1), DAU (X2) dan DAK (X3) sama dengan nol, angka Belanja Modal (Y) berjumlah -20,888 satuan; (2) Angka koefisien $\beta_{1}=0,648$ menjelaskan jika angka PAD $\left(\mathrm{X}_{1}\right)$ bertambah 1 satuan, angka Belanja Modal (Y) akan meningkat berjumlah 0,648 satuan dengan ceteris paribus; (3) Angka koefisien $\beta_{2}=5,289$ menjelaskan jika angka DAU $\left(\mathrm{X}_{2}\right)$ bertambah 1 satuan, angka Belanja Modal (Y) akan meningkat berjumlah 5,289 satuan dengan ceteris paribus; (4) Angka koefisien $\beta_{3}=0,014$ menjelaskan jika angka DAU (X3) bertambah 1 satuan, angka Belanja Modal (Y) akan meningkat berjumlah 0,014 satuan dengan ceteris paribus.

Tabel 6.

Uji Kesesuaian Model

\begin{tabular}{llcl}
\hline \multicolumn{1}{c}{ Model } & F & Sig \\
\hline 1 & Regresion & 17.931 & .000 \\
& Residual & & \\
$\quad$ Total & & \\
Sumber: Data Diolah, 2017 & &
\end{tabular}


Pada Tabel 6. menjelaskan angka sig $=0,000$ signifikan pada $\alpha=5 \%$. Hasil ini bisa disimpulkan model regresi berganda sudah memenuhi uji kelayakan model.

Tabel 7.

Uji Koefisien Determinasi

\begin{tabular}{cccc}
\hline Model & R & R Square & Adjusted R Square \\
\hline $\mathbf{1}$ & 0.837 & .700 & .661 \\
\hline Sumber: Data Diolah, 2017 & &
\end{tabular}

Pada Tabel 7. dapat diketahuin koefisien determinasi dengan hasil angka R2 sebesar 0,661 atau 66\%. Hasil perhitungan $66 \%$ menerangkan PAD, DAU dan DAK terpengaruh dengan Belanja Modal sejumlah 66\% sedangkan $44 \%$ sisanya dipengaruhi oleh variabel lain.

Pengujian Hipotesis pada Tabel 8. dilakukan untuk mengukur seberapa jauh pengaruh masing-masing variabel independen secara parsial dalam menerangkan variasi variabel dependen. Pada Tabel 8. Perhitungan hasil antara variabel bebas terhadap variabel terikat diantaranya dapat dijelaskan pada Tabel 8 yaitu :

Tabel 8.

Uji Hipotesis

\begin{tabular}{ccccccc}
\hline \multirow{2}{*}{ Model } & \multicolumn{2}{c}{$\begin{array}{c}\text { Unstadarized } \\
\text { Coefficiens }\end{array}$} & $\begin{array}{c}\text { Standarized } \\
\text { Coefficients }\end{array}$ & \multirow{2}{*}{ t } & Sig \\
\cline { 3 - 5 } & & $\mathrm{B}$ & Std. Error & Beta & & \\
\hline \multirow{2}{*}{1} & (Constant) & -20.888 & 9.469 & & -2.206 & .038 \\
& PAD & .648 & .285 & .264 & 2.271 & .033 \\
& DAU & 5.289 & .789 & .800 & 6.707 & .000 \\
& DAK & .014 & .006 & .278 & 2.323 & .029 \\
\hline
\end{tabular}

Sumber: Data Diolah, 2017

PAD $\left(\mathrm{X}_{1}\right)$ terhadap Belanja Modal (Y) didapatkan angka sig 0,033 yang menjelaskan PAD signifikan pada Belanja Modal karena angka sig dibawah dari 0,05. Angka koefisien PAD $\left(\mathrm{X}_{1}\right)$ 0,648 menjelaskan PAD positif terhadap Belanja Modal. Angka tersebut menunjukkan $\mathrm{H}_{1}$ diterima. 
DAU $\left(\mathrm{X}_{2}\right)$ terhadap Belanja Modal $(\mathrm{Y})$ didapatkan angka sig 0,000 yang menjelaskan DAU signifikan pada Belanja Modal karena angka sig dibawah dari 0,05. Angka koefisien DAU $\left(\mathrm{X}_{2}\right)$ 5,289 menjelaskan DAU positif terhadap Belanja Modal. Angka tersebut menunjukkan $\mathrm{H}_{2}$ diterima.

DAK $\left(\mathrm{X}_{3}\right)$ terhadap Belanja Modal (Y) didapatkan angka sig sebesar 0,029 yang menjelaskan DAK signifikan pada Belanja Modal karena angka sig dibawah dari 0,05. Angka koefisien DAK $\left(\mathrm{X}_{3}\right)$ 0,014 menjelaskan DAK positif terhadap Belanja Modal. Angka ini menunjukkan $\mathrm{H}_{3}$ diterima.

\section{Pembahasan Pengaruh Setiap Variabel}

\section{Pengaruh PAD terhadap Belanja Modal}

Adanya pengaruh positif PAD kepada Belanja Modal memiliki penjelasan bahwa PAD yang semakin tinggi, maka Belanjan Modalnya semakin tinggi juga yang bisa dialokasikan oleh pemerintah daerah. Pendapatan Asli Daerah atau PAD yang meningkat akan memberikan manfaat untuk meningkatkan penyediaan fasilitas publik melalui pembangunan saran dan prasarana terutamanya pembangunan infrastruktur. Dengan ditemukannya hasil penelitian ini, diharapkan masing-masing daerah dapat menggali potensi penerimaan daerahnya secara maksmial. PAD positif terhadap Belanja Modal dapat memberikan penjelasan bahwa Hasil-penelitian-ini sejalan dengan-penelitian dilaksanakan oleh-Gounder $e t$ al., (2007), Lucky (2013) dan-Abba (2015) yang menemukan bahwa PAD positif terhadap Belanja Modal.

\section{Pengaruh DAU terhadap Belanja Modal}


Adanya pengaruh positif DAU kepada belanja modal dapat memberikan penjelasan bahwa Dana Alokasi Umum memiliki keterikatan dengan pembangunan infrastruktur daerah. Kerterkaitan dengan pembangunan infrastuktur daerah dapat dikatakan karena bantuan berupa DAU yang dikirimkan dari nasional dan dipergunkan pemda ditujukan untuk mendanai kegiatan atau program pemerintah daerah melalui belanja daerah terutamanya Belanja Modal. DAU yang semakin besar diberikan dari pusat, maka Belanja Modal akan semakin besar yang dianggarkan (Novianto dan Hanafiah, 2015). Dengan hasil temuan ini menunjukkan pemda berketergantungan dengan dana perimbangan yang dialokasikan pemerintah pusat untuk daerah dalam mendanai kegiatan daerahnya.

Hasil penelitian ini mendukung penelitian Sumarsono dan Rahmawati (2017), Abdillah and Mursinto (2016) yang menemukan bahwa DAU positif terhadap Belanja Modal

\section{Pengaruh DAK terhadap Belanja Modal}

DAK yaitu bantuan besumber dari APBN yang diberikan untuk suatu daerah tertentu bertujuan untuk mendana kegiatan yang menjadi keperluan daerah dengan mengikuti kebijakan dan program pembangunan nasional berdasarkan UU No.33 Tahun 2004. Pengaruh positif DAK terhadap belanja modal dapat memberikan penjelasan Dana Alokasi Khusus yang dialokasikan melalui APBN oleh pusat dan diberikan kepada pemda untuk peningkatan keperluan daerah sesuai dengan kebijakan dan program nasional mampu meningkatkan infrastruktur sarana dan prasarana, fasilitas publik melalui peningkatan Belanja Modal. Pemberian bantuan 
pemerintah pusat melalui Dana Alokasi Khusus untuk pemerintah daerah salah satu tujuannya yaitu membiayai kebutuhan penyediaan sarana dan prasarana fisik terutamanya infrastruktur (Novianto dan Hanafiah, 2015).

Hasil penelitian ini mendukung penelitian Sugiyanta (2016) dan Novianto dan Hanafiah (2015) yang menemukan bahwa DAK positif terhadap Belanja Modal.

\section{Implikasi Hasil Penelitian}

Implikasi hasil penelitian ini mengarah kepada manfaat penelitian secara nyata terhadap hasil penelitian dengan tujuan mengetahui pengaruh penerimaan daerah terhadap Belanja Modal. Anggaran Belanja Modal dipergunakan meningkatkan pembangunan fasilitas dan infrastruktur. Berikut beberapa implikasi penelitian yang diperoleh.

Pertama, dari penelitian ini dapat dibuktikan bahwa jika pemerintah daerah jika meningkatkan sumber pemasukan dari Pendapatan Asli Daerah akan meningkatkan penyediaan infrastruktur dan fasilitas publik yang sesuai dengan keperluan daerah. Meningkatnya Pendapatan Asli Daerah, maka mampu memberikan manfaat meningkatkan pembangunan daerah terutamanya infrastruktur dan fasilitas publik yang ada di daerah baik kota ataupun kabupaten yang tersebar di Provinsi Bali.

Kedua, dari penelitian ini dapat dibuktikan bahwa dalam peningkatan pemberian bantuan dari pusat berupa Dana Alokasi Umum akan menigkatkan pembangunan infrastruktur dan penyediaan fasilitas publik daerah. Dana Alokasi 
Umum diberikan karena masing-masing daerah tidak mempunyai kemampuan keuangan yang sama dalam membiayai aktivitas-aktivitas pemerintahannya. Penelitian ini menemukan bahwa Pemerintah daerah masih bergantung terhadap kebijakan pusat diataranya dana perimbangan yang diberikan oleh pemerintah pusat kaitannya dengan mendanai peneydiaan fasilitas dan infrastruktur publik meliputi sarana dan prasarana.

Ketiga, dari penelitian ini dapat dibuktikan bahwa Pemberian bantuan berbentuk Dana Alokasi Khusus yang diberikan pemerintah pusat untuk pemerintah daerah kaitannya dengan mendanai program atau kegiatan keperluan setiap daerah sesuai kebijakan dan program nasional sudah bermanfaat dan digunakan untuk meningkatkan fasilitas publik dan pembangunan infrastruktur terutamanya pembangunan kota dan kabupaten di Provinsi Bali melalui alokasi Belanja Modal.

\section{SIMPULAN DAN SARAN}

Pada penjelasan permasalahan, kajian-teori-dan hasil perhitungan yang-telah dijelaskan, maka-penelitian-ini diambil kesimpulannya diantaranya (1) PAD positif terhadap Belanja Modal pada kota dan kabupaten di Provinsi Bali. Adanya pengaruh positif PAD kepada Belanja Modal memiliki penjelasan bahwa PAD yang semakin tinggi, maka Belanjan Modalnya semakin tinggi juga yang bisa dialokasikan oleh pemerintah daerah. Pendapatan Asli Daerah atau PAD yang meningkat akan memberikan manfaat untuk meningkatkan penyediaan fasilitas publik melalui pembangunan saran dan prasarana terutamanya pembangunan infrastruktur. (2) DAU positif terhadap Belanja Modal pada kota dan kabupaten di Provinsi Bali. Adanya pengaruh positif DAU kepada alokasi belanja modal dapat 
memberikan penjelasan bahwa Dana Alokasi Umum memiliki keterikatan dengan pembangunan infrastruktur daerah. Kerterkaitan dengan pembangunan infrastuktur daerah dapat dikatakan karena bantuan berupa DAU yang dikirimkan dari nasional dan dipergunkan pemda ditujukan untuk mendanai kegiatan atau program pemerintah daerah melalui belanja daerah terutamanya Belanja Modal. (3) DAK positif terhadap Belanja Modal pada kota dan kabupaten di Provinsi Bali. Pemberian dana pemerintah pusat untuk daerah berbentuk DAK untuk pemerintah daerah kaitannya mendanai kebutuhan program nasional yang sesuai cakupan daerah digunakan untuk peningkatan fasilitas publik dan pembangunan infrastruktur melalui peningkatan Belanja Modal. Pemberian DAK yang semakin tinggi oleh pemerintah pusat, maka Belanja Modal akan meningkat dalam kaitannya dengan pembangunan yang seragam dengan program nasional. (4) Pemerintah Daerah Provinsi Bali belum cukup mandiri dalam mendanai Belanja Modalnya. Pemerintah daerah dalam penelitian ini memiliki pengaruh yang besar dengan dana perimbangan yang diberikan oleh pusat yang berkaitan dengan melaksanakan pemerintahan membiayai penyediaan sarana dan prasarana, fasilitas dan infrastruktur fasilitas publik. Berdasarkan hasil temuan, dapat dikatakan pemda masih memiliki ketregantungan terhadap pemerintah pusat.

Saran yang bisa diajukan yang sesuai dengan kesimpulan yang diperoleh dalam penelitian ini diantaranya. (1) Pemerintah Provinsi diharapkan mendorong daerahnya yang terdiri dari satu kota dan delapan kabupaten agar dapat menggali lebih banyak sumber Penerimaan daerah yang berupa Pendapatan Asli Daerah termasuk diantaranya keuntungan daerah yang diperoleh melalui pajak daerah, 
pemasukan dari retribusi daerah, pemasukan dari pengelolaan aset daerah agar terhindar dari ketergantungan finasial dari pusat dalam pembangunan infrastruktur dan penyediaan fasilitas publik. (2) Pemerintah daerah diharapkan dapat meningkatkan penerimaan daerah melalui memanfaatkan sumber daya yang tersedia di setiap daerah. Meingkatkan PAD merupakan salah salah satu cara untuk menghindari kebergantungan pemerintah daerah pada pemerintah pusat terutamnya mengenai finansial daerah. (3) Penelitian selanjutnya diharapkan memperpanjang rentang waktu penelitian diantaranya menggunakan periode sepuluh tahun serta menggunakan variabel bebas lainnya seperti jenis penerimaan lainnya, ukuran pencapaian kinerja dan pertumbuhan ekonomi. Penelitian berikutnya dengan menggunakan variabel bebas lainnya diharapkan dapat menjelaskan secara lengkap faktor apa saja yang mempengaruhi Belanja Modal.

\section{REFERENSI}

Abba, Mohammed., Ahmed, Bawa Bello., and Salihu, Aliyu Modibbo. 2015. Expenditure and Internally Generated Revenue Relationship: An Analysis of Local Governments in Adamawa State, Nigeria. Journal of Arts, Science and Commerce, 6(1), pp: 67-77.

Abdillah, Khubbi and Mursinto, Djoko. 2016. The Effects of Financial Balance Transfer and Regional Own-Source Revenue on Regional Expenditure of Regencies and Municipalities in East Java Province. International Journal of Scientific and Research Publications, 6(5), pp: 26-30.

Adyatama, Erdi dan Oktaviani, Rachmawati Meita. 2015. Pengaruh Pendapatan Asli Daerah dan Dana Alokasi Umum terhadap Belanja Modal dengan Pertumbuhan Ekonomi Sebagai Moderasi. Dinamika Akuntansi, Keuangan dan Perbankan, 4(2), hal.190-205.

Arini dan Mustika, Made Dwi Setyadi. 2015. Pengaruh Pendapatan Asli Daerah dan Belanja Tidak Langsung terhadap Kemiskinan melalui Pertumbuhan Ekonomi di Provinsi Bali Tahun 2007-2013. E-Jurnal EP Unud, 4(9), hal.1048-1193.

Ayinde, Kayode., Kuranga, John., and Rukman., Adewale F. 2015. Modelling Nigerian Goverment Expenditure, Revenue and Economic Growth: Co- 
integration, Error Connection Merchanism and Combined Estimators Analysis Approach. Asian Economic and Financial Review, 5(6), pp: 858867.

Bagchi, Debraj. 2015. Bihar State Finance : A Story of Central Support. Journal of Economic Policy and Research, 11(1), pp: 115-125.

Basri, Faisal. 2002. Perekonomian Indonesia: Tantangan dan Harapan Bagi Kebangkitan Ekonomi Indonesia. Jakarta: Erlangga.

Febriana, Imas Sherli dan Praptoyo, Sugeng. 2015. Analisis Faktor Yang Mempengaruhi Belanja Modal Pada Provinsi Jawa Timur. Jurnal Ilmu \& Riset Akuntansi, 4(9), hal. 1-22.

Felix, Olurankinse. 2012. Analysis of the Effectiveness of Capital Expenditure Budgeting in the Local Government System of Ondo State, Nigeria. Journal of Accounting and Taxation, 4(1), pp: 1-6.

Gounder, Neelesh., Narayan, Paresh Kumar., and Prasad, Arti. 2007. An Empirical investigation of the relationship between government revenue and expenditure: The Case of the Fiji Islands. International Journal of Social Economics , 34(3), pp: 147-158.

Halim, Abdul. 2014. Manajemen Keuangan Sektor Publik: Problematika Penerimaan dan Pengeluaran Pemerintah. Jakarta: Salemba Empat.

Heliyanto, Firnandi dan Handayani, Nur. 2016. Pengaruh PAD, DAU, DAK, DBH Terhadap Pengalokasian Anggaran Belanja Modal. Jurnal Ilmu dan Riset Akuntansi, 5(3), pp: 1-17.

Henley, D., Holtham, C., Likierman, A., and Perrin, J. 1990. Public Sector Accounting and Financial Control, 3rd Edition. London: Chapman and Hall.

Jaya, I Putu Ngurah Panji Kartika dan Dwirandra, A.A.N.B. 2014. Pengaruh Pendapatan Asli Daerah pada Belanja Modal dengan Pertumbuhan Ekonomi sebagai Variabel Pemoderasi. E-Jurnal Akuntansi Universitas Udayana, 7(21), hal.79-92.

Keputusan Menteri Dalam Negeri Nomor 29 Tahun 2002. Pedoman Pengurusan, Pertanggungjawaban dan Pengawasan Keuangan Daerah. 10 Juni 2002. Jakarta.

Lucky, Dihar. 2013. Analysis Of The Effect Of Regional Financial Performance To Economic Growth and Poverty Through Capital Expenditure (Case study of 38 Regencies/Cities in East Java Province). Journal of Economics and Sustainable Development, 4(19), pp: 7-17.

Mahmudi. 2010. Manajemen Keuangan Daerah. Jakarta: Penerbit Erlangga.

Martini, Ni Luh Dina Selvia., Cipta, Wayan., dan Suwendra, I Wayan. 2014. Pengaruh Pendapatan Asli Daerah, Dana Alokasi Umum dan Dana Alokasi Khusus terhadap Belanja Modal pada Kabupaten Buleleng tahun 2006-2012. 
e-Journal Bisma Universitas Pendidikan Ganesha Jurusan Manajemen, 2(10), hal.1-12.

Mbedzi, Edson., and Gondo, Tendayi. 2010. Fiscal Management In Dangila Municipality Ethiophia. Performance and Policy Implications, 5(14), pp: 95119.

Nani, Richard Doh., and Awunyo-Vitor, Dadson. 2012. The Causal Link between Government Expenditure and Government Revenue in Ghana. Asian Economic and Financial Review, 2(2), pp: 382-388.

Nurlis. 2016. The Factors Affecting of the Capital Expenditure Allocation Case: The Local Government of Indonesia. Research Journal of Finance and Accounting, 7(1), pp: 107-113.

Novianto, Riko., dan Hanafiah, Rafiudin. 2015. Pengaruh Pendapatan Asli Daerah, Dana Perimbangan dan Kinerja Keuangan terhadap Belanja Modal pada Pemerintah Kabupaten/Kota di Provinsi Kalimantan Barat. Jurnal Ekonomi, 4(1), hal.1-22.

Paramartha, Made Fajar dan Budiasih, I Gusti Ayu Nyoman. 2016. Analysis Flypaper Effect, Pendapatan Asli Daerah, Dana Alokasi Umum dan Dana Alokasi Khusus pada Belanja Modal. E-Jurnal Akuntansi Universitas Udayana, 15, hal.1536-1564.

Pentury, Marten Anthon. 2011. Flypaper Effect Anomaly Of West Papua Capital Public Expenditure. Economic Journal of Emerging Markets, 3(3), pp: 289297.

Peraturan Pemerintah Republik Indonesia Nomor 71 Tahun 2010. Standar Akuntansi Pemerintahan. 22 Oktober 2010. Lembaran Negara Republik Indonesia tahun 2010 Nomor 123. Jakarta.

Peraturan Menteri Dalam Negeri Nomor 13 Tahun 2006. Pedoman Pengelolaan Keuangan Daerah. 15 Mei 2006. Jakarta

Permatasari, Isti., dan Mildawati, Titik. 2016. Pengaruh Pendapatan Daeah terhadap Belanja Modal pada Kabupaten/Kota Jawa Timur. Jurnal Ilmu dan Riset Akuntansi, 5(1), hal.1-17.

Purbarini, Endah., and Masdjojo, Gregorius N. 2015. Flypaper Effect Tracer On Operating Expenditure and Capital Expenditure of City Government in Indonesia. South East Asia Journal of Contemporary Business, Economics and Law, 7(3), pp: 9-15.

Saragih, Juli Panglima . 2003. Desentralisasi Fiskal dan Keuangan Daerah dalam Otonomi. Jakarta : Ghalia Indonesia.

Sugiyanta. 2016. Analisis Belanja Modal dan Faktor-Faktor yang Mempengaruhinya Pada Pemerintah Kabupaten/Kota Di Indonesia. Jurnal Akuntansi Universitas Jember, 14(1), hal. 19-40. 
Sukarna, Wiranta. 2013. Keuangan Daerah dan Pelayanan Publik. Yogyakarta : P3DI Setjen DPR Republik Indonesia dan Azza Grafika.

Sumarsono, Dr. Hadi., and Rahmawati, Dr. Farida. 2017. The Phenomenon Flypaper Effect in Balanced Funds, Regional Revenue and Surplus Budget Funding of Economic Growth and Regional Expenditure in Districts/City East Java Province. IOSR Journal of Economics and Finance (IOSR-JEF), 8(1), pp: 42-52.

Susanti, Susi., dan Fahlevi, Heru. 2016. Pengaruh Pendapatan Asli Daerah, Dana Alokasi Umum dan Dana Bagi Hasil terhadap Belanja Modal. Jurnal Ilmiah Mahasiswa Ekonomi Akuntansi (JIMEKA), 1(1), hal.183-191.

Tuasikal, Askam. 2008. Pengaruh DAU, DAK, PAD dan PDRB Terhadap Belanaj Modal Pemerintah Daerah Kabupaten/Kota di Indonesia. Jurnal Telaah \& Riset Akuntansi, 1(2), hal.142-155.

Undang-undang Nomor 32 Tahun 2004. Pemerintah Daerah.15 Oktober 2004. Lembaran Negara Republik Indonesia Tahun 2004 Nomor 125. Jakarta.

Undang-undang Nomor 33 Tahun 2004. Perimbangan Keuangan Antara Pemerintah Pusat dan Pemerintah Daerah. 15 Oktober 2004. Lembaran Negara Republik Indonesia Tahun 2004 Nomor 126. Jakarta.

V, Sebastiana., and Cahyo, Herman. 2016. Analysis of Economic Performance as The Independence Indicators of Government in East Java Province. Review of Integrative Business and Economics Research, 5(2), pp: 289-297.

Venkataraman, Subramanya., and Urmi, Arabi. 2017. Development Expenditure, Fiscal Consolidation and Public Revenue in India. International Journal of Accounting and Economic Studies, 5(1), pp: 16-18.

Wahyuningsih, Panca., dan Widaryanti. 2015. Peningkatan PAD dan DAU terhadap Belanja Modal di Kabupaten dan Kota di Provinsi Jawa Timur. Jurnal Dinamika Ekonomi dan Bisnis, 12(1), hal. 33-48. 